\title{
COMPARATIVE ANALOGIES: SULLIVAN VISITS THE COMMONWEALTH
}

\author{
Marie-France Major
}

In three recent decisions, the courts of three different countries have used the comparative method to fashion a judicial solution to a particular problem. In trying to reconcile free speech issues with concerns for the protection of individual reputations, the House of Lords in Derbyshire County Council, ' the High Court of Australia in Theophanous, ${ }^{2}$ and the Supreme Court of Canada in Hill $^{3}$ all referred to the American decision of Sullivan. ${ }^{4}$ An examination of these decisions demonstrates the tendency of courts to engage in comparative analysis when faced with difficult problems. ${ }^{5}$ They also illustrate how the comparative method and comparative materials constitute a source of inspiration for legal decisions by offering a wide array of solutions. $^{6}$

The three recent Commonwealth decisions are clear examples of the different ways in which foreign materials can be used by courts. ${ }^{7}$ The English decision illustrates how courts can engage in comparative analysis to extrapolate general principles which are then applied to a particular issue. The Australian decision demonstrates how national courts can refer to foreign jurisprudence to copy or fashion a solution to the problem they are faced with, whereas the Canadian decision shows how courts can use the comparative method in order to reject a particular solution.

\section{The Issue: Defamatory PUblication}

In Derbyshire, Theophanous, and Hill, plaintiffs had brought defamation actions and were seeking damages for loss of reputation. The issue before the courts was whether the persons who had published or uttered damaging words

* Marie-France Major, B.Sc.Soc. (Ottawa), LL.B. (Ottawa), B.C.L. (Oxford), J.S.D. (Berkeley), is Associate Professor in the Faculty of Law at the University of Ottawa (Canada).

1. Derbyshire CC v. Times Newspapers Lid., All E.R. 1011 (1993).

2. Theophanous v. Herald \& Weekly Times Ltd. (1994) 124 A.L.R. 1 (Austl.).

3. Hill v. Church of Scientology [1995] 2 S.C.R. 1130 (Can.).

4. New York Times Co. v. Sullivan, 376 U.S. 254 (1964).

5. See T. Koopmans, Comparative Law and the Courts, 45 INT'L \& CoMP. L.Q. 545 (1996).

6. See KONRAD ZWEIGERT \& HEIN KOTZ, INTRODUCTION TO COMPARATIVE LAW 15 (1987). See also ALAN WATSON, LEGAL TRANSPLANTS (1974) (providing positive and negative aspects of comparative analysis).

7. For further discussion of the uses of the comparative method, see W. J. Kamba, Comparative Law: A Theoretical Framework, 23 INT'L \& COMP. L.Q. 485 (1974); Rene Cassin, Droits de L'homme et Méthode Comparative, REVUE INT. DE DROIT COMPARÉ 449 (1968); Peter de CRUZ, A MODERN APPROACH TO COMPARATIVE LAW (1993); ZWEIGERT \& KOTZ, supra note 6. 
could escape liability. To resolve that issue, the courts had to examine whether the existing defamation laws established an appropriate balance between two sets of conflicting values: those of reputation and those of freedom of expression.

The defamation laws which the courts had before them essentially established that, in order to recover damages, a plaintiff had to prove that the material complained of was defamatory and that it referred to the plaintiff. Inferences of falsity and malice favored the plaintiff. ${ }^{8}$ Defendants, in turn, could defend themselves by pleading justification, fair comment, or privilege. ${ }^{9}$ Thus, a person who published an assertion of fact or a comment was guilty of a tort and liable for damages unless he or she could positively justify or excuse the publication in the particular circumstances of the case. Proof of the publication of the defamatory statement discharged the plaintiff's onus and cast upon the defendant the burden of establishing some defense.

\section{THE SOURCE: NEW YORK TIMES $\nu$. SULLIVAN 10}

The action in Sullivan arose because of an editorial advertisement placed in the New York Times. The advertisement, which supported the civil rights movement, specifically referred to and described an incident of police abuse in Montgomery, Alabama. Despite not being mentioned by name, Sullivan, who was an elected commissioner from Montgomery, sued the New York Times for libel. ${ }^{11}$ A jury awarded him $\$ 500,000$ in damages. ${ }^{12}$

On appeal, the Supreme Court reversed the decision..$^{13}$ Referring to the First Amendment guarantee of freedom of expression, the Court placed restrictions on the operation of the law of defamation. The Court affirmed that, when allegations which would ordinarily be defamatory were made of a public official in relation to his official conduct, an action by him would not succeed unless he proved with convincing clarity that, at the time the defamatory statements were made, the defendant either knew them to be false

8. In defamation proceedings a plaintiff bears no onus of establishing either the falsity of the defamatory statement or the existence of malice.

9. See generally R. BROWN, THE LAW Of Defamation IN CANADA (2d ed. 1994); Robert Martin, Media LaW (1997); Peter F. CARTER-Ruck et al., CarTer-RuCK on LIBEL AND SLANDER, (4th ed. 1992); JOHN G. FLEMING, THE LAW OF TORTS (8th ed. 1992).

10. See New York Times Co. v. Sullivan, 376 U.S. 254 (1964).

11. Sullivan, whose particular duty was to supervise the police department, argued that the advertisement would be read as referring to him. $J d$. at 258 .

12. This amount was awarded despite the fact that only 35 copies of the edition of the New York Times which carried the advertisement were circulated in Montgomery, and only 394 copies were circulated in the state of Alabama. Id. at 260 n.3.

13. The Alabama Supreme Court had upheld the amount of damages. Id. at 256 . For discussion of the Sullivan decision, see ANTHONY LEWIS, MAKE No LAW: THE SULLIVAN CASE AND THE FIRST AMENDMENT (1991). 
or was reckless as to whether they were or not. ${ }^{14}$ In the Court's view, only this standard would provide sufficient "breathing space" for criticism of public officials, and for the "profound national commitment to the principle that debate on public issues should be uninhibited, robust, and wide-open." Is

Two principles were established in Sullivan. The first being that the Bill of Rights reaches judicial orders enforcing the libel laws of a state in private litigation. The common law of defamation constitutes government action because the application of the Constitution depends on the fact of state power. ${ }^{16}$ The second principle is that the common law presumptions of falsity and malice impose an unconstitutional fetter upon freedom of speech, for they have a tendency to "chill expression." Since critics of official conduct must guarantee the truth of all factual assertions or else suffer libel judgements, they are bound to engage in self-censorship. ${ }^{17}$

The crux of the Court's argument is that allowance of the defense of truth, with the burden of proving it on the defendant, does not guarantee that only false speech is deterred. It is often too difficult to prove the truth of the alleged libel in all its factual particulars. Under the existing rule, "would-be critics of official conduct may be deterred from voicing their criticism, even though it is believed to be true and even though it is in fact true, because of doubt whether it can be proved in court or fear of the expense of having to do so." 18 The traditional common law rule not only assures that critics shy away from making controversial statements but it also has the effect of limiting the diversity of public debate. ${ }^{19}$ The Sullivan test is thus premised on the notion that a rule which has a "chilling effect" on speech constitutes a greater evil than a rule which permits false information to enter the public arena.

\section{The SEARChERS: The COMmonwealth COMES A'LOOKING}

In Theophanous, in Derbyshire and in Hill, national courts examined whether the modifications engrafted upon the common law of libel by the United States Supreme Court were appropriate for them. ${ }^{20}$ They had to decide

14. See Sullivan, 376 U.S, at 280 . The standard of "convincing clarity" is more rigorous than the preponderance of the evidence standard which normally applies in civil actions.

15. Id. at 270 .

16. The Court affirmed that "[i]t matters not that that law has been applied in a civil action and that it is common law only, though supplemented by statute." Id. at 265 . In its view, "[t]he test is not the form in which state power has been applied but, whatever the form, whether such power has in fact been exercised." Id.

17. Jd. at 279.

18. Id.

19. Id.

20. This issue also recently arose in India. In Rajogopal v. State of Tamil Nadu (1994) 6 S.C.C. 524, the Indian Supreme Court, following Sullivan, held that a public official cannot recover libel damages for a false and defamatory publication about his official conduct unless 
whether their free speech jurisprudence should follow the American path. ${ }^{21}$ The debate was therefore whether, and to what extent, they should import foreign rules and a foreign philosophy into their own legal and political culture.

\section{Australia's SOlution}

The Theophanous ${ }^{22}$ case arose out of defamation proceedings which were initiated by a member of the Commonwealth Parliament against a newspaper. The newspaper had published a letter to the editor that was critical of the representative's views and competence. One of the defenses raised by the newspaper was based on the implied freedom of political communication in the Australian Constitution. ${ }^{23}$

The court started its decision by confirming the existence of an implied freedom of communication with respect to discussion of government and political matters. ${ }^{24}$ This implied freedom of communication was not limited to communication between the electors and the elected. Rather, it extended to members of society generally. ${ }^{25}$ Since the publication at issue related to the views, performance, and capacity of a member of Parliament, the publication

he proves that the publication was made with reckless disregard for truth.

21. For a discussion of the importance of free speech within each country, see generally Michael Kirby, Freedom of Expression-Some Recent Australian Developments, 19 COMMONWEALTH L. BULL. 1778(1993); W. S. Tamopolsky, Freedom of Expression in Canada, 19 COMMONWEALTH L. BULL. 1769 (1993); and Lord Woolf of Bames, Freedom of Expression: An English Perspective, 19 CommonWealth L. BuLl. 1743 (1993).

22. See Theophanous v. Herald \&Weekly Times Ltd. (1994) 124 A.L.R. I (Austl.). For discussion of the decision and of its impact, see A. E. Cassimatis, Defamation-The Constitutional Public Officer Defence, TORT L. REV. 25 (1996); Timothy H. Jones, Freedom of Political Communication in Australia, 45 INT'L \& COMP. L.Q. 392 (1996); Ian Loveland, Australia Takes the Plunge, 146 N.L.J. 1558 (1996); James A. Thomson, Slouching Towards Tenterfield: The Constitutionalization of Tort Law in Australia, 3 TORT L. REV. 81 (1995); F. A. Trindale, 'Political Discussion' and the Law of Defamation, 111 LAWQ. REV. 199 (1995); and Sally Walker, The Impact of the High Court's Free Speech Cases on Defamation Law, 17 SYDNEY L.R. 43 (1995).

23. Theophanous, 124 A.L.R. at 11. The defendants claimed that the "freedom of communication" principle offered a defense even to false information in certain circumstances. The principle was first used to invalidate Acts criminalizing criticism of government bodies and prohibiting party political advertisements on television and radio. See Australian Capital Television v. Commonwealth of Australia (1992) 108 A.L.R. 577 and Nationwide News Party v. Wills (1992) 108 A.L.R. 681. In those two cases, the High Court extrapolated from the provisions of the Australian Federal Constitution, and more particularly from the concept of representative government, an implied freedom of communication in relation to "political discussion." The court affirmed that this implied freedom was necessary to ensure the efficacious working of representative democracy.

24. Three of the court's seven members joined a plurality opinion authored by Chief Justice Mason. Justice Deane concurred in the result but wrote a separate judgment.

25. Theophanous, 124 A.L.R. at 12. 
fell within the range of "political discussion."26

In examining the relationship and links that exist between the implied freedom and the common law, the court maintained that whenever the Constitution, expressly or by implication, is at variance with a doctrine of the common law, it is the latter which must yield to the former. ${ }^{27}$ According to the court, "when the purpose of the implication is to protect the efficacious working of the system of representative government mandated by the Constitution, the freedom which is implied should be understood as being capable of extending to freedom from restraints imposed by law, whether statute law or common law."28

The court then turned its attention to the question of whether the existing laws of defamation inhibited freedom of communication. Relying on American jurisprudence, the court affirmed that "an implication of freedom of communication, the purpose of which is to ensure the efficacy of representative democracy, must extend to protect political discussion from exposure to onerous criminal and civil liability if the implication is to be effective in achieving its purpose."29 The court's position was that the balance of the law of defamation was tilted too far in favor of the protection of the reputation of individual politicians, at the expense of freedom of communication and the efficient functioning of the democratic society. ${ }^{30}$ The problem with the existing law was that it "seriously inhibit[ed] freedom of communication on political matters, especially in relation to the views, conduct and suitability for office of an elected representative of the people in the Australian Parliament." 31

Having determined that the existing law of defamation was unconstitutional, the court then went on to articulate which principles would be consistent with the implied constitutional guarantee. In its view, Australian constitutional law required that a disseminator of false information about politicians' behavior in, and suitability for, public office have a complete defense to a defamation claim brought by politicians if they could demonstrate (a) that they "[were] unaware of the falsity of the material published"; (b) that they "did not publish the material recklessly, that is, not caring whether the material was true or false"; and (c) that "publication was reasonable in the

26. Id.

27. Id. at 15 .

28. Id. at 16-17.

29. Id. at 18.

30. Id. at 20. The court dismissed the argument that the common law reflected an appropriate balance between the competing interests of freedom of expression and the protection of the rights of defamed individuals. The common law, in the opinion of the court, could not do so because "the courts have not taken account of the fact that there is an implied freedom of communication." Id. at 19.

31. Id. at 23. 
circumstances." ${ }^{32}$ To establish reasonableness defendants must either show that they took some steps to check the accuracy of the impugned material or show that it was otherwise justified in publishing without taking such steps or steps which were adequate. ${ }^{33}$

The plurality's decision in Theophanous was clearly influenced by the Sullivan decision, ${ }^{34}$ despite the warnings of Chief Justice Mason that American jurisprudence should be "treat[ed] with some caution"3s in light of the fact that American constitutional provisions relating to speech are different from those found in Australia. While the First Amendment protects in an explicit way freedom of expression generally, the Australian Constitution protects, in an implicit fashion only, freedom of communication in matters of political discussion, and only because such speech constitutes an indispensable element in ensuring the efficacious working of democracy and government. ${ }^{36}$

The Australian court utilized the Sullivan judgment to bolster its decision that "freedom of communication" could not be construed simply as a negative constraint on legislative power and that the freedom had to be respected by all governmental agencies, including the courts, when interpreting statutes and applying the common law. ${ }^{37}$ It further referred to

32. Id. at 26. Justice Deane, the fourth member of the majority, would have gone further in the application of the implied constitutional guarantee. His position was that the constitutional guarantee operated so as "to preclude completely the application of ... defamation laws to impose liability in damages upon the citizen for the publication of statements about the official conduct or suitability of a member of the Parliament or other holder of [a] high Commonwealth office." Id. at 61 . He rejected the idea of importing the Sullivan test into Australian law, for such a test did not sufficiently protect political communications. Id. at 5961.

33. The High Court also expanded the defense of qualified privilege in relation to defamatory communications made in newspapers in the course of "political discussion." Id. at 25-26.

34. See also Ian Loveland, Sullivan v. The New York Times Goes Down Under, 1996 PUB. L. 126.

35. Theophanous, 124 A.L.R. at 14.

36. In dissent, Justice Brennan argued that the plurality should not have invoked the Sullivan decision to the extent it did. His position was that "the assistance which cases decided under other Constitutions or Conventions can give in determining the scope of the freedom is extremely limited." Id. at 39. American jurisprudence, in Justice Brennan's opinion, should be referred to with caution because the United States Constitution is different from the Australian Constitution and because the history which has affected the interpretation of the First and Fourteenth Amendments is different from Australia's history. Id. at 41 . He rejected Sullivan as a model for the Australian court because "[i]n this country, following the long tradition of the common law, we have accepted that personal reputation is a proper subject of protection, no less for those in public office as for private citizens." Id.

37. Id. at 16-17. Despite Justice Brennan's argument that comparisons with other jurisdictions were pointless, he nonetheless referred to the Canadian Charter of Rights and the Canadian decisions establishing that judicial decisions do not constitute "governmental action." Id. at 42-43. 
Sullivan to support its conclusion that defamation laws constitute effective tools for politicians to "chill" free speech. ${ }^{38}$ Having determined that existing defamation laws were unconstitutional, the plurality also invoked Sullivan to support its belief that the efficacious workings of representative democracy and government did not demand that all actors involved in political discussions be granted an absolute immunity. If the Sullivan Court had rejected an absolutist approach, then surely the Australian court, with only its implicit guarantee, need not fashion an absolute exemption. ${ }^{39}$

It is when formulating a test or a list of criteria to be used to determine liability or non-liability in defamation actions that differences between the positions of the American and Australian courts arise. While continuing to refer to the Sullivan decision, the Australian court does so in a different manner. At this point, the court begins by pointing out the problems associated with the American decision. This technique allows the court to distance itself from the Sullivan solution and to justify its own position. Having hailed the Sullivan judgment in the first part of its decision, the Australian court must explain why it decided not to incorporate into Australian law the "actual malice" test developed in the United States. Thus the Australian court, within the same judgment, both hails the beneficial effects of the Sullivan decision and emphasizes criticism associated with it.

Although the test developed by the Australian court is clearly influenced by the decision in Sullivan, it departs from American law in significant ways. Most notably, the Australian defense articulated in Theophanous operates only in respect of "political discussion." After criticizing the United States Supreme Court's extension of the Sullivan rationale to candidates for political office, public administrators, and public figures, the Australian court observed "that these extensions, other than the extension to cover candidates for public office, should not form part of our law."40

The court in Theophanous further distanced itself from American law by stipulating that the burden of proving the three parts of the Australian

38. Id. at 18-20. As Loveland posits, the court accepted that the common law chilled freedom of speech in Australia without any empirical evidence. His position is that "the absence of any reference at all to the political difficulties that libel law has caused in modem Australia ... opens the court to the accusation that it has simply been seduced by grand theory and compelling rhetoric." See Loveland, supra note 34, at 130.

39. Theophanous, 124 A.L.R. at 20-21. The court refers to Justice Black's judgment in Sullivan but explains that his absolutist views were rejected by Justice Brennan.

40. Id. at 21. Earlier in its judgment, the court affimed "that political discussion includ[ed] discussion of the conduct, policies or fitness for office of government, political parties, public officers and those seeking public office." Id. at 13. "The concept also includ[ed] discussion of the political views and public conduct of persons who are engaged in activities that have become the subject of political debate...." Id. The court acknowledged the difficulty of drawing a distinction between political discussion and other forms of expression but argued that "it should be possible to develop, by means of decisions in particular cases, an acceptable limit to the type of discussion which falls within the constitutional protection." Id. 
defense (that is, no knowledge of falsehood, absence of recklessness, and reasonableness) rested on the defendant. It justified this departure on the grounds that the laws of the United States give insufficient weight to individual reputation. ${ }^{41}$ Its solution was to adopt a variant of the Sullivan test, a variant that would recognize more clearly the values of Australian culture. The court thus went to great lengths to make clear that it was not adopting or introducing into Australian jurisprudence the actual malice test created in Sullivan.

The Australian judgment demonstrates how the comparative technique can be utilized by courts. When faced with difficult questions, especially constitutional questions, national courts can learn from the experience of other countries. Foreign jurisprudence can be used to demonstrate the desirability of reforming domestic laws as well as the impact that such reforms may have. ${ }^{42}$ Furthermore, the decision illustrates that domestic courts need not, and must not, uncritically import foreign rules into their national systems. Foreign legal rules that work in another system, may need to be adapted to reflect the realities and differences, be they cultural, constitutional, or economic, of the importing country. ${ }^{43}$

\section{THE UNITED KINGDOM QUANDARY}

In Derbyshire, a municipal council brought a defamation action against the publisher of a newspaper. The claim for damages arose from articles concerning the authority's management of certain funds. The issue before the courts was whether a local authority could sue for libel in respect of "words which reflect on it in its governmental and administrative functions."44 Although at first instance the court rejected the newspaper's contention that councils lacked the legal capacity to bring a libel action over criticism of their

41. The court affirmed that "[e]ven assuming that, in conformity with Sullivan, the test is confined to plaintiffs who are public officials, in our view it gives inadequate protection to reputation." Id. at 22. It further held that "the protection of free communication does not necessitate such a subordination of the protection of individual reputation as appears to have occurred in the United States." Id. at 23. For discussion of the lack of importance of individual reputation in American society, see Frederick Schauer, Social Foundations of the Law of Defamation: A Comparative Analysis, 1 J. MEDIA L. \& PRAC. 1 (1980).

42. While courts must examine the actual nules developed in other jurisdictions, they must go further than simply examining and referring to one particular court decision. National courts must also examine how such foreign rules have been interpreted, as well as the impact such rules have actually had. See Michael Chesterman, The Money or the Truth: Defamation Reform in Australia and the USA, 18(2) UNSW L.J. 300 (1995).

43. As Loveland explains, "[u]ncritical importation of foreign rules cannot . . . be acceptable . . . because of the uniqueness of Australia's political culture-against which American or other principles might chafe and rub." Loveland, supra note 34, at 139.

44. Derbyshire CC v. Times Newspapers Ltd., All E.R. 1013 (1993). 
"governing reputation," of Lords upheld the decision of the Court of Appeal but on different grounds. ${ }^{47}$

While the Court of Appeal had resorted to the European Convention on Human Rights to decide that a local authority could not sue in defamation to protect its governmental reputation, the House of Lords found no reason to rely on the Convention. ${ }^{48}$ Lord Keith, writing for the majority, argued that considerations of policy were determinative of the issue. Because governmental bodies are different from other corporations, they must be "open to uninhibited public criticism." Anyone who attempts to stifle or fetter such criticism commits "political censorship of the most insidious and objectionable kind."so In the Court's view, the problem with allowing governmental entities to have recourse to civil actions for defamation, is that it would "inevitably have an inhibiting effect on freedom of speech."51

Lord Keith relied on United States, Commonwealth, and South African authorities to support his policy arguments to the effect that the threat of civil actions for libel have a tendency to chill speech. He had no misgivings in referring to, and utilizing, the arguments expounded in Sullivan to support his conclusions. ${ }^{52}$ His position was to the effect that the public interest considerations which underlay the Sullivan decision were equally valid in English law. ${ }^{53}$ This, despite the fact that Britain does not possess an express constitutional guarantee of the right of free speech that is equivalent to the

45. 4 All E.R. 795 (1991). Justice Morland held that a local authority, like all other corporations, could sue for libel.

46. 1 Q.B. 770 (1992).

47. For discussion of the decision, see Alistair Bonnington, Public Figure v. Private Person, 147 N.L.J. 270 (1997) and Lord Lester of Heme Hill, Comment, Defaming Politicians and Public Officials, 1995 PUB. L. 1.

48. Lord Keith did affirm, however, that in the field of freedom of expression, there was no difference in principle between English law on the subject and article 10 of the Convention. Derbyshire, All E.R. at 1021. For a discussion of this issue, see also Ian Loveland, Defaming MPs: A Question of Constitutional Law?, 146 N.L.J. 714 (1996) and Stephanie Palmer, Freedom of Expression, Democracy and the European Convention on Human Rights, 52 C.L.J. 363 (1993).

49. Derbyshire, All E.R. at 1017.

50. Id. at 1018.

51. Id. at 1017.

52. That the Lords would refer to American case law is somewhat surprising, since, as late as 1991, the Report on Defamation Law and Practice recommended that the philosophy of Sullivan should not be adopted into English law. See Report on Practice and Procedure in Defamation, Supreme Court Procedure Committee (Neil, L.J., Chairman), Lord Chancellor's Department (1991); Bonnington, supra note 47, at 270.

53. Derbyshire, All E.R. at 1018. Nowhere is the influence of the Sullivan decision more evident than in Lord Keith's observations that "[q]uite often the facts which would justify a defamatory publication are known to be true, but admissible evidence capable of proving those facts is not available. This may prevent the publication of matters which it is very desirable to make public." Id. 
American First Amendment, ${ }^{54}$ and despite the fact that British society, unlike American society, adheres to a system of parliamentary sovereignty. ${ }^{5 s}$

The decision of the Lords was therefore that, under the common law of England, a local authority does not have the right to maintain an action of damages for defamatory matter reflecting on its governmental and administrative functions. ${ }^{56}$ Their position was to the effect that not only is there no public interest favoring the right of governmental bodies "to sue for libel, but that it is contrary to the public interest that they should have it. It is contrary to the public interest because to admit such actions would place an undesirable fetter on freedom of speech." ${ }^{157}$ The Lords also maintained that although local authorities could not initiate defamation actions, individual councillors could do so. ${ }^{58}$

Despite engaging in comparative analysis and referring to the decision in Sullivan, ${ }^{59}$ the House of Lords did not adopt or incorporate the actual malice test into English law. ${ }^{60}$ The reality is that they did not fashion any test

54. The Lords nowhere explain the divergent conceptions of reputation which exist in the United States and in England. Traditionally, English libel law has attached more weight to reputation rights than the United States. See Eric Barendt, Libel and Freedom of Speech in English Law, 15 P.L. 449, 457 (1994); Thomas Gibbons, Defamation Reconsidered, 16 OXFORD J. OF LEGAL STUDIES 587 (1996); Lord Woolf of Barnes, supra note 21. For the American position on the importance of reputational rights, see supra note 41.

55. See Ian Loveland, Defamation of 'Government': Taking Lessons from America?, 14 LEGAL STUD. 206, 222-25 (1994).

56. Local authorities can protect their reputation by using alternate remedies. For example, they could start actions for malicious falsehoods or they could simply defend themselves through more speech of their own.

57. Derbyshire, All E.R. at 1019.

58. Id. at 1020. According to Lord Keith, a publication that attacks the activities of the authority "will necessarily be an attack on the body of councillors which represents the controlling party, or on the executives who carty on the day-to-day management of its affairs. If the individual reputation of any of these is wrongly impaired by the publication any of these can himself bring proceedings for defamation." $I d$.

59. References to American cases stopped with the 1964 Sullivan decision. Lord Keith did not find it necessary to discuss the impact the decision has had on the actual development of libel law in the United States. As Loveland explains, "[i]n conducting only so cursory a survey of the United States' constitutional landscape, Lord Keith decline[s] to mine a seam of case law which, while undoubtedly unstable, nevertheless offers an extraordinary rich array of raw materials from which to sculpt several considered arguments as to how extensive a scope should be afforded to any reform of libel law." See Loveland, supra note 55, at 212-13.

60. As Loveland and Sharland point out, "[t]here seems to be little sympathy among English judges for the direct importation of Sullivan into domestic common law." Andrew Sharland \& lan Loveland, The Defamation Act 1996 and Political Libels, 1997 PUB. L. 113, 123. An attempt to introduce an amendment to have the public figure concept recognized in the Defamation Bill in 1996 was unsuccessful. According to Loveland and Sharland, "given that such reforms were omitted from the $1996 \mathrm{Act}$, it would seem inappropriate for the courts to take such an initiative." Id. Under English law, therefore, there is no recognition of a general privilege to defame a prominent individual who holds a public position on the grounds that what is said expresses the writer's honest and reasonable belief on a matter which is one of public 
that resembles the one expounded in that decision. In fact, by ruling that public authorities are completely precluded from starting libel actions, the Lords set aside the Sullivan rationale to the effect that the First Amendment does not afford complete immunity to public officials from libel suits. ${ }^{61}$

What the Derbyshire court does, is invoke Sullivan and American jurisprudence to extrapolate general principles. Thus, Sullivan is relied on to establish the importance of free speech in the context of criticism of government and to explain that libel laws are worrisome since they have a tendency to "chill" freedom of speech. Having set out these principles, the Lords then rely on them as justification to revise the political libel laws of England. If free speech in the context of political discussion merits protection and if libel laws have a chilling effect, then surely courts are warranted in giving priority to speech claims over those of other competing interests.

\section{THE CANADIAN APPROACH}

The proceedings in Hill arose after representatives of the Church of Scientology and their counsel Manning held a press conference outside a courthouse. $^{62}$ At this conference, Manning commented upon allegations contained in a notice of motion by which Scientology intended to start criminal proceedings against Crown attomey Casey Hill. The notice of motion alleged that Hill had misled a judge and had breached orders sealing certain documents belonging to the Church of Scientology. ${ }^{63}$ After contempt proceedings, which determined that the allegations against the Crown attorney were untrue and without foundation, Hill commenced an action for damages in libel ${ }^{64}$ Both the Church of Scientology and its counsel were found to have defamed Hill. ${ }^{65}$

Before the Supreme Court, Manning and the Church of Scientology invoked the Canadian Charter of Rights and Freedoms. ${ }^{66}$ Their allegation was to the effect that the common law of defamation unreasonably restricted free expression. ${ }^{67}$ In their view, for the common law of defamation to

interest. See Blackshaw v. Lord, Q.B. 1, 26 (1984).

61. See Barendt, supra note 54 , at 452.

62. Hill v. Church of Scientology [1995] 2 S.C.R. 1130, 1140 (Can.).

63. Id. at 1 140-41. Manning was wearing a barrister's gown when he spoke to the media.

64. Id. at 1141 .

65. Following the trial, Manning and the Church of Scientology were found jointly liable for general damages in the amount of $\$ 300,000$. The Church of Scientology was also found liable for aggravated damages of $\$ 500,000$ and for punitive damages of $\$ 800,000$. The appeal from this judgment was dismissed by the Court of Appeals. See [1994] 18 O.R.3d 385.

66. Part I of the Constitution Act, 1982, being Schedule B to the Canada Act 1982 (U.K.), 1982 , c. 11.

67. The appellant attorney also raised the defense of qualified privilege which attaches to reports relating to judicial proceedings. 
establish a proper balance between the values of reputation and expression, the actual malice standard of liability articulated in Sullivan had to be adopted. ${ }^{68}$

In its judgment, the court reaffirmed ${ }^{69}$ that although the Charter could not be applied directly to scrutinize the common law of defamation in private litigation, ${ }^{70}$ it had to be developed in accordance with Charter values. ${ }^{71}$ To determine whether the common law of defamation complied with the underlying values of the Charter, the court examined whether the common law struck an appropriate balance between the competing values of reputation and freedom of expression. ${ }^{2}$ Despite recognizing that freedom of expression is crucial to democratic society, the court argued that defamatory speech is only tenuously related to the core values which underlie section 2(b) of the Charter. ${ }^{73}$ The court also affirmed that the protection of a person's reputation

68. Hill, 2 S.C.R. at $1158-59$.

69. In R.W.D.S.U. v. Dolphin Delivery Ltd. [1986] 2 S.C.R. 573, the court addressed the Charter's application to the common law. Its decision was to the effect that the Charter does not apply where a private action is governed by the common law but that the Charter does apply to the common law in " public litigation." The court acknowledged that, even though the Charter did not apply to the common law in the context of private litigation, the Charter would affect the common law because the judiciary should "apply and develop the principles of the common law in a manner consistent with the fundamental values enshrined in the Constitution." Id. at 603. For further discussion of the issue, see June Ross, The Common Law of Defamation Fails to Enter the Age of the Charter, XXXV ALBERTA L. REV. 117 (1996).

70. For discussion of the different approaches of the Canadian and American courts on this subject, see John G. Fleming, Libel and Constitutional Free Speech, in INTERNATIONAL ACADEMY OF COMPARATIVE LAW, XIIITH INTERNATIONALCONGRESS-GENERALREPORTS 673 (1990).

71. "[T]he party who alleges that the common law is inconsistent with the Charter... bear[s] the onus of proving both that the common law fails to comply with Charter values and that, when those values are balanced, the common law should be modified." Hill, 2 S.C.R. at 1171.

72. According to the court, "whatever is 'added to the field of libel is taken from the field of free debate." Id. at 1172 (quoting Sweeney v. Patterson, 128 F.2d 457, 458 (D.C. Cir. 1942)). For the view that defamation law in Canada accords too much protection to individual reputation, see Rodney A. Smolla, Balancing Freedom of Expression and Protection of Reputation Under Canada 's Charter of Rights and Freedoms, in FREEDOM OFEXPRESSION AND THE ChARTER 272 (David Schneiderman ed., 1991), and D. A. Alderson, The Constitutionalization of Defamation: American and Canadian Approaches to Constitutional Regulation of Speech, 15 ADVOC. Q. 385 (1993).

73. Hill, 2 S.C.R. at 1174. According to the Court, "defamatory statements . . a are inimical to the search for truth." Id. They do not "enhance self-development" and they do not "lead to ... participation in the affairs of the community." Id. False and injurious statements are not only "detrimental to the advancement of these values," but they are "harmful to the interests of a free and democratic society." Id.; but see M. David Lepofsky, Making Sense of the Libel Chill Debate: Do Libel Laws "Chill" the Exercise of Freedom of Expression?, 1994 NAT. J. CONST. L. 168 (questioning the Supreme Court of Canada's interpretation of section 2(b) of the Charter). 
from defamatory speech constitutes a worthy interest in a democratic society. ${ }^{74}$ Having established the importance of reputation within Canadian society, the court then turned its attention to Sullivan. Since it did not wish to incorporate the actual malice test into Canadian law, the court sought to distance itself from that decision. To this end, the court affirmed that the social and political context within which Sullivan arose was completely different from the one that existed in Hill. ${ }^{75}$ In Sullivan, the speech involved was political; the media was entangled in the conflict, and there existed fears that the existing defamation laws would have a chilling effect on the media. ${ }^{76}$ On the other hand, the appeal in Hill did not involve political commentary about government policies and the media was not directly implicated in the conflict. ${ }^{77}$ The Court also noted that government officials in Canada, contrarily to the situation in the United States, did not enjoy the benefit of a qualified privilege as regards to their public statements. ${ }^{78}$ Its position was that "in Canada[,] there is no broad privilege accorded to the public statements of government officials which needs to be counterbalanced by a similar right for private individuals." 79

To demonstrate the dangers associated with the American solution, the court focused on American academic and judicial ${ }^{80}$ criticism of the actual malice rule. Dissatisfaction with the achievements of the decision rests on the fact that, since Sullivan, "libel actions have increased ... in both number and size of awards." ${ }^{81}$ The increase in litigation and the requirements of actual malice have also put "pressure on the fact-finding process since courts are now required to make determinations as to who is a public figure and what is a matter of ... public concern." 82 Furthermore, the decision, according to the court, has shifted the focus of defamation actions from truth to fault. The

74. The Court linked protection of individual reputation with rights of privacy and personal dignity. Its position was that "although it is not specifically mentioned in the Charter, the good reputation of the individual represents and reflects the innate dignity of the individual, a concept which underlies all the Charter rights." Hill, 2 S.C.R. at 1179.

75. According to the court, "[n]one of the factors which prompted the United States Supreme Court to rewrite the law of defamation in America are present in the case at bar." Id. at 1188 .

76. Id. at $1180-81$.

77. Id. at 1 188. After reviewing jury verdicts in Canada, the court was of the opinion that "there is no danger of numerous large awards threatening the viability of media organizations." Id.

78. In the United States, government officials enjoy a qualified privilege with respect to materials published in the course of conducting the affairs of government.

79. Hill, 2 S.C.R. at 1188.

80. The court referred to Justice White's judgment in Dun \& Bradstreet, Inc. $v$. Greenmoss Builders, Inc., 472 U.S. 749 (1985) and to the dissenting opinion of two Justices in Coughlin v. Westinghouse Broadcasting \& Cable Inc., 476 U.S. 1187 (1986).

81. Hill, 2 S.C.R. at 1182.

82. Id. 
detrimental results associated with this change include: denial of opportunity for the plaintiff to "establish the falsity of the defamatory statements and to determine the consequent reputational harm"; necessity of "detailed inquiry into matters of media procedure"; "increase[s in] the cost of litigation; and a depreca[tion of] truth in public discourse." ${ }^{\text {3 }}$

In order to emphasize that rejecting the American solution would not mean that Canada stood alone in protecting individual reputation above freedom of expression, the court referred to the English and Australian decisions in Derbyshire and in Theophanous. It pointed out that both the House of Lords and the High Court of Australia recently declined to adopt the Sullivan actual malice requirement. ${ }^{84}$ For added measure, the court mentioned that numerous international law reform organizations have also criticized the Sullivan rule. ${ }^{85}$

The court's conclusion was to the effect that, since the Sullivan standard of liability was the subject of much criticism in the United States and elsewhere and since the actual malice standard rule had "not been followed in the United Kingdom or Australia, [there was] no reason for adopting it in Canada in an action between private litigants." law of defamation not "unduly restrictive or inhibiting", but it "surely [was] not requiring too much of individuals that they ascertain the truth of the allegations they publish." common law of defamation complie[d] with the underlying values of the Charter" in its application to the parties in that action, there was "no need to amend or alter it." 88

Despite using the comparative method to fashion its judgment, the court did not engage in an extensive comparative analysis. ${ }^{89}$ Although it had before it foreign jurisprudence which specifically examined how free speech and reputational interests could best be reconciled in the context of defamation laws, the court, in assessing the approaches and solutions adopted by foreign countries, focused mainly on criticism surrounding the American solution..$^{90}$

83. Id. at $1182-83$.

84. Id. at 1185-86. Interestingly, the court did discuss the fact that both Australian and English courts have recognized that defamation laws have a tendency to "chill speech." Id.

85. Id. at $1186-87$.

86. Id. at 1187.

87. Id.

88. Id. at 1188.

89. For discussion of the use of the comparative method within Canada, see Jose Woehrling, Le Rôle du Droit Comparé Dans la Jurisprudence des Droits de la PersonneRapport Canadien, in THE LIMITATION OF HUMAN RIGHTS IN COMPARATIVE CONSTITUTIONAL LAW 449 (Armand de Mestral et al. eds., 1986).

90. Courts in New Zealand have also focused on the criticism surrounding the Sullivan decision in order to justify their rejection of the actual malice test. See Grant Huscroft, David Lange and the Law of Defamation, 1997 N.Z.L.J. 112. 
Although the court referred to the decisions in Theophanous and in Derbyshire, it did so only to point out that both cases specifically rejected the "malice" standard of liability. Thus, it barely addressed the Australian and English courts' conclusions that libel laws "chill" speech" and it ignored the Australian High Court's affirmation that despite some degree of balancing in the common law, the judges who developed it were not concerned with freedom of expression in a constitutional sense and so did not give it adequate weight in their balancing process. ${ }^{92}$ Furthermore, the Canadian court did not address in what ways the Australian court chose to modify the common law. Such a stratagem is not surprising, considering that the Supreme Court's invocation of foreign jurisprudence was mainly to buttress its initial conclusion that the malice standard should not be adopted in Canadian law.

\section{CONCLUSION}

Traditionally, one area of law where courts are prone to engage in comparative analysis is that of constitutional law. When dealing with fundamental rights issues such as free expression, national courts often turn to foreign jurisprudence to examine how other countries have sought to reconcile free expression rights with other competing values and what solutions they have found to particular problems. ${ }^{93}$ Foreign jurisprudence is useful since it provides a yardstick by which to measure the desirability and the impact that particular reforms may have.

One factor which plays a crucial role in determining whether a foreign solution should be transplanted elsewhere is the international standing of the donor country. ${ }^{94}$ It is always easier and more feasible for a mational court to refer to, and to adopt, a foreign solution when it emanates from a country that commands both economic and legal respect within the world community. ${ }^{95}$

91. The court simply criticized the lack of "any evidentiary basis upon which to adjudicate [the] constitutional attack." Hill, 2 S.C.R. at 1163.

92. That the court ignored this factor is suprising since this very same court had invoked it in Dagenais v. Canadian Broadcasting Corp. [1994] 3 S.C.R. 835 (Can.).

93. See generally Albrecht Weber, The Role of Comparative Law in the Civil Liberties Jurisprudence of the German Courts, in THE LIMITATIONS OF Human Rights IN COMPARATIVE CONSTITUTIONAL LAW 525 (Armand de Mestral et al eds., 1986); Helmut Steinberger, General Report on the Role of Comparative Law In Civil Liberties Jurisprudence, in THE LIMITATIONS OF HUMAN RIGHTS IN COMPARATIVE CONSTITUTIONAL LAW 575 (Armand de Mestral et al eds., 1986).

94. For a discussion of the issue, see WATSON, supra note 6 , chs. $7,8,15$.

95. The high respect accorded to the American Supreme Court, especially as regards its jurisprudence in the area of free speech, is clearly evident in all three Commonwealth decisions. While the Canadian Supreme Court ultimately decides not to adopt the American approach on the issue of libel, it does not dismiss the Sullivan decision as inconsequential. Indeed, before rejecting the American solution, the court goes to great lengths in demonstrating the negative aspects associated with the decision. 
Another factor is that of sheer quantity. As more countries lean towards a particular position, it becomes more difficult for a national court to go against the tide. While the argument can be made that one country has made a mistake in adopting a particular solution, it becomes much more difficult to advance that numerous countries which have examined a somewhat identical issue have taken the wrong path. ${ }^{96}$

While national courts may rely on comparative materials in order to find a solution to the problem they are faced with, they need not blindly adopt the foreign approach. ${ }^{97}$ As the decisions in Theaphonous, Derbyshire, and Hill demonstrate, foreign solutions are not necessarily appropriate for a particular country. This is particularly true whenever the answer to a problem requires that courts involve themselves in a balancing of values. ${ }^{98}$ Values, after all, have a direct link to cultural identity. ${ }^{99}$

The existence of such links, however, does not mean that courts should shy away from comparative analogies. By pointing out that different solutions to a problem are possible, such analogies often force courts to re-evaluate their own position as regards the weight to be accorded to certain values. In the area of libel law, for example, an examination of the Sullivan decision forced Canadian, Australian, and English courts to ask themselves why, if, and to what extent, they should protect reputational rights above free speech rights.

96. Herein lies one of the dangers associated with comparative analogies. National courts may find it easier to simply incorporate into their own systems ready-made rules that are widely accepted rather than seek innovative solutions that require time to formulate and that are subject to criticism both at the national and the international level. This problem, however, is somewhat offset by the fact that legal rules are rarely transplanted wholly from one system to another. The process of modification which usually accompanies the act of transplanting ensures that legal rules are constantly being reformulated.

97. The issue of whether courts should engage in comparative analogies is somewhat different from that of whether foreign solutions should be incorporated without modifications into different settings. While numerous authors agree that comparative analogies are useful (see, for example, Koopmans, supra note 5), few go so far as to advance that the process of transplanting should proceed without any modifications (see, for example, ZWEIGERT \& KÖTZ, supra note 6 , at 16 ). One must also remember that, although a national court may seem to be adopting the language of a particular foreign rule or decision, once transplanted, the rule may operate in a totally different way within the receiving society than it does within the donor country. For further discussion of this issue, see WATSON, supra note $6, \mathrm{ch} .3$.

98. While one could advance that in many areas of law legal rules are "not peculiarly devised for the particular society in which they now operate" (see WATSON, supra note 6, at 96), such argument has less force within the constitutional sphere. When national courts develop constitutional rules, more often than not, these rules are formulated to operate within a particular context since they reflect and incorporate a set of national values.

99. For further discussion of this issue, see Sidney Kentridge, Freedom of Speech: Is It the Primary Right, 45 INT'L \& COMP. L.Q. 253 (1996) and Robert Post, The Social Foundations of Defamation Law: Reputation and the Constitution, 74 CAL. L. REV. 691 (1986). 
At the very least, the comparative analogy in Theaphonous, Derbyshire, and Hill provided national courts with assistance in framing the legal and cultural questions that they had to address. 
